\title{
EFISIENSI EKONOMI FAKTOR PRODUKSI PADA USAHATANI BROKOLI DI KELURAHAN KAKASKASEN
}

\author{
Juliana R. Mandei \\ Christy P. Tuwongkesong
}

\begin{abstract}
The study aims to determine the efficiency of use of factors of production in Broccoli farming. Research carried out on all Broccoli farmers in Kakaskasen Village. Data were analyzed using multiple linear regression analysis with a model of Cobb-Douglas production function. The results showed that the uses of factors of production (land, seed, fertilizer and labor) have given a significant effect simultantly on the production of broccoli in Kakaskasen Village. Technically, the use of production factors of seed, fertilizer, NPK fertilizer and labor is efficient, while the use production factor of land is not efficient yet and Urea fertilizer production factor is not efficient. Economically, the use of production factors of land, seed, fertilizer, NPK fertilizer and labor have not been efficient yet, while the use of factors of production of urea is not efficient.
\end{abstract}

Keywords: efficiency, production factors, Broccoli farming

\begin{abstract}
Abstrak
Penelitian ini bertujuan untuk mengetahui efisiensi penggunaan faktor produksi pada usahatani Brokoli. Penelitian dilakukan terhadap seluruh petani Brokoli yang ada di Kelurahan Kakaskasen. Data dianalisis dengan menggunakan analisis regresi linier berganda dengan menggunakan model fungsi produksi Cobb-Douglas. Hasil penelitian menunjukkan bahwa penggunaan Faktor Produksi lahan, benih, pupuk dan tenaga kerja, secara bersama-sama berpengaruh nyata terhadap produksi brokoli di Kelurahan Kakaskasen. Secara teknis, pengunaan faktor produksi benih, pupuk kandang, pupuk NPK dan tenaga kerja sudah efisien, sedangkan penggunaan faktor produksi lahan belum efisien dan penggunaan factor produksi pupuk Urea sudah tidak efisien.Secara ekonomis, penggunaan factor produksi lahan, benih, pupuk kandang, pupuk NPK dan tenaga kerja masih belum efisien, sedangkan penggunaan factor produksi pupuk Urea sudah tidak efisien.
\end{abstract}

Kata kunci : Efisiensi, faktor produksi, usahatani Brokoli

\section{PENDAHULUAN}

\section{Latar Belakang}

Brokoli (Brassica oleracea)merupakan salah satu tanaman hortikultura yang mempunyai serat gizi yang tinggi yang penting bagi kebutuhan manusia.Kelurahan Kakaskasendi kota Tomohon merupakan salah satu daerah yang mempunyai potensi untuk pengembangan tanaman ini. Tanaman ini merupakan tanaman yang masih baru dikembangkan di daerah ini. Oleh karena itu penelitian tentang penggunaan faktor produksi belum pernah dilakukan padahal penggunaan faktor produksi dan penerapan teknologi memegang peran penting dalam usahatani Brokoli.
Tersedianya sarana atau faktor produksi (input) belum berarti produktifitas yang diperoleh petani akan tinggi. Namun bagaiman petani melakukan usahanya secara efisien adalah upaya yang sangat penting. Kurang tepatnya penerapan teknologi mengakibatkan rendahnya produksi dan tingginya biaya usaha tani. Dalam usaha tani, produksi yang dihasilkan akan baik apabila faktor-faktor produksi dimanfaatkan secara efisien (Zulkifly, 2009).Untuk memperoleh keuntungan maksimal maka petani harus menggunakan faktor produksi secara tepat,dan mengkombinasikan secara optimal dan efisien. Oleh karena itu, perlu 
dilakukan penelitian mengenai efisiensi penggunaan faktor-faktor produksi pada usahatani brokoli.

\section{Perumusan masalah}

Dari latar belakang masalah diatas yang telah dikemukakan maka dapatdirumuskan permasalah sebagai berikut: bagaimana penggunaan faktor produksi pada usahatani brokoli di Kelurahan Kakaskasen?

\section{Tujuan dan Manfaat Penelitian}

Untuk mengetahui efisiensi penggunaan faktorfaktor produksi pada usahatani brokoli di Kelurahan Kakaskasen. Manfaat dari penelitian ini adalah memberikan informasi tentang penggunaan faktorfaktor produksi yang optimal.

\section{TINJAUAN PUSTAKA}

\section{Konsep Fungsi Produksi}

Produksi adalah suatu kegiatan yang mengubah input menjadi output. Kegiatan tersebut dalam ekonomi biasa dinyatakan dalam fungsi produksi. Fungsi produksi merupakan potret dari hubungan fisik input-output. Fungsi produksi sering didefenisikan sebagai fungsi yang menjelaskan hubungan fisik antara jumlah input yang dikorbankan dengan jumlah maksimum output yang dihasilkan. Fungsi produksi mendifinisikan kemungkinan produksi yang terbuka bagi manajer atau pengambilan keputusan mengenai tingkatan transformasi sumber daya (factor input) kedalam bentuk produksi (Dillon \& Hardaker 1990).

Fungsi produksi dapat dinyatakan dalam berbagai cara: (a) dalam bentuk tertulis, menyatakan rincian input dan output; (b) dalam bentuk tabel yang memuat kuantitas input dan output; (c) dalam bentuk grafik; dan (d) dalam bentuk persamaan aljabar. Secara simbolis sebuah fungsi produksi dapat di tulis sebagai berikut:

$$
Q=f\left(X_{1}, X_{2}, X_{3}, \ldots \ldots X_{n}\right)
$$

Dimana Q adalah output, X1...Xn adalah bermacam-macam input yang berkontribusi dalam menghasilkan output Q. Input-input yang digunakan dalam proses produksi ada yang tergolong input tetap dan input variable. Peran input tetap adalah mengaborsi dan mentransformasikan input-input variable kedalam output. Secara simbolis, input tetap dapat ditandai dengan meletakan sebuah garis vertical diantara input variable dan input tetap, sebagai berikut.

$$
\mathrm{Q}=\mathrm{f}\left(\mathrm{X}_{1}, \mathrm{X}_{3} \mid \mathrm{X}_{2}, \ldots . \mathrm{Xn}_{-1}, \mathrm{X}_{\mathrm{n}}\right)
$$

Yang menyatakan bahwa X2,....Xn-1, Xn adalah input tetap, sedangkan yang lainnya (X1, X3) adalah input variabel. Fungsi produksi mengekspresikan tentag perubahan taraf output (Q) dengan bertambahnya kuantitas input (X), yang berlangsung dengan sejumlah input tetap (unit teknis) yang tersedia, dan teknologi yang ada.

Untuk dapat menjelaskan hubungan fisik antara input dan output, banyak model yang telah dikembangkan. Hubungan antara faktor produksi dan output dapat di gambarkan melalui fungsi produksi cobb-douglas. Bentuk sederhana dari fungsi tersebut adalah:

$$
\mathrm{Q}=\beta_{0} \mathrm{~L}^{\beta 1} \mathrm{~K}^{\beta 2} \varepsilon
$$

Dimana $: \mathrm{Q}=$ output

$$
\begin{aligned}
& \mathrm{L}=\text { tenaga kerja } \\
& \mathrm{K}=\text { Modal }
\end{aligned}
$$

Fungsi tersebut dapat diperluas dengan menambahkan faktor produksi.

Heady dan Dillon (1961) menggunakan fungsi Cobb-Douglas dalam penelitian untuk menggambarkan hubungan antara output dengan input lahan, tenaga kerja, modal, dan manajemen. Secara matematis model yang digunakan dalam penelitiannya adalah sebagai berikut :

$$
\mathrm{Y}=\beta_{0} \mathrm{X}_{1}{ }^{\beta 1} \mathrm{X}_{2}{ }^{\beta 2} \mathrm{X}_{3}{ }^{\beta 3} \mathrm{X}_{4}{ }^{\beta 4} \varepsilon
$$

Model tersebut menggambarkan fungsi cobbdouglas dimana output (Y) merupakan fungsi dari input lahan $\left(\mathrm{X}_{1}\right)$, tenaga kerja $\left(\mathrm{X}_{2}\right)$, modal $\left(\mathrm{X}_{3}\right)$ dan manajemen $\left(\mathrm{X}_{4}\right)$.

Dalam usahatani brokoli, faktor-faktor produksi yang digunakan adalah Lahan, Tenaga 
kerja, Benih, Pupuk Kandang, Pupuk Urea dan Pupuk NPK.

Dengan demikian model fungsi produksi CobbDouglas yang digunakan untuk menggambarkan hubungan antara factor produksi dan produksi brokoli sebagai berikut:

$\mathrm{Yi}=\beta_{0} \mathrm{X}_{1}^{\beta 1} \mathrm{X}_{2}{ }^{\beta 2} \mathrm{X}_{3}{ }^{\beta 3} \mathrm{X}_{4}{ }^{\beta 4} \mathrm{X}_{5}{ }^{\beta 5} \mathrm{X}_{6}{ }^{\beta 6} \varepsilon$

Dengan bentuk logaritme menjadi :

$\ln \mathrm{Yi}=\ln \beta_{0}+\beta_{1} \operatorname{Ln} \mathrm{X}_{1}+\beta_{2} \ln \mathrm{X}_{2}+\beta_{3} \ln \mathrm{X}_{3}+$ $\beta_{4} \ln X_{4}+\beta_{5} \ln X_{5}+\beta_{6} \ln X_{6}+\ln \varepsilon$

dimana :

Yi $=$ Produksi Brokoli $(\mathrm{kg})$

$\mathrm{X}_{1}=$ Luas Lahan (ha)

$\mathrm{X}_{2}=$ Jumlah Tenaga Kerja $(\mathrm{HOK})$

$\mathrm{X}_{3}=$ Jumlah Benih

$\mathrm{X}_{4}=$ Jumlah Pupuk Kandang $(\mathrm{kg})$

$\mathrm{X}_{5}=$ Jumlah Pupuk Urea

$\mathrm{X}_{6}=$ Jumlah Pupuk NPK $(\mathrm{kg})$

Hal menarik dari fungsi produksi Cobb-Douglas adalah koefisien regresi dari masing-masing faktor produksi menunjukkan elastisitas dari masingmasing faktor produksi.

\section{Efisiensi Penggunaan Faktor Produksi}

\section{Usahatani}

Pengertian efisiensi sangat relative, efisiensi diartikan sebagai penggunaan input sekecilkecilnya untuk mendapatkan produksi yang sebesar-besarnya. Situasi yang demikian akan tejadi kalau nilai produk marginal (NPM) untu suatu input sama dengan harga input dapat dituliskan :

Dimana :

$$
\operatorname{NPM}_{\mathbf{X i}}=\mathbf{P}_{\mathbf{X i}}
$$

$\mathrm{NPM}_{\mathrm{Xi}}=$ Nilai produk marginal

perubahan input

$$
\mathrm{P}_{\mathrm{Xi}} \quad=\text { Harga input }
$$

Soekartawi (2002) mengemukakan bahwa prinsip optimalisasi penggunaan faktor produksi pada prinsipnya bagaimana mengunakan faktor produksi tersebut seefisien mungkin. Dalam terminologi ilmu ekonomi, maka pengertian efisien ini dapat digolongkan menjadi 3 macam, yaitu:

1. Efisiensi teknis ; suatu pengunaan faktor produksi dikatakan efisien secara teknis kalau faktor produksi yang dipakai menghasilkan produksi maksimum . Efisiensi teknis akan tercapai pada saat elastisitas produksi (EP) berada diantara nol dan satu $(0<\mathrm{Ep}<1)$. Bila Ep $>$ 1; maka produksi total (TP) menaik pada tahap increasing rate dan produksi rata-rata (PR) juga naik. Hal ini terjadi pada tahap 1, disini penambahan input faktor produksi akan meningkatkan produksi total maupun produksi rata-rata. Karena itu hasil yang diperoleh dari penambahan input faktor masih jauh lebih besar dari tambahan biaya yang harus dibayarkan. Daerah ini merupakan daerah produksi yang belum efisien atau pengunaan faktor-faktor produksi belum optimum. Bila Ep $<0$; penambahan input faktor justru menurunkan produksi total. Pada daerah ini pemakaian faktor produksi sudah tidak efisien lagi dan disebut daerah irasional.Keuntungan masih dapat di-tingkatkan selama nilai kenaikan hasil masih lebih besar dari nilai tambahan faktor produksi yang dipergunakan.

2. Efisiensi alokatif (efisiensi harga): dikatakan efisiensi harga atau efisiensi alokatif kalau nilai dari produk marginal sama dengan harga faktor produksi yang bersangkutan.

3. Efisiensi ekonomi: dikatakan efisiensi ekonomi kalau usaha pertanian tersebut mencapai efisiensi teknis dan sekaligus juga mencapai efisiensi harga.

\section{METODOLOGI PENILITIAN}

\section{Metode Pengumpulan Data}

Data yang dikumpulkan dalam penelitian ini meliputi data primer diperoleh dari hasil wawancara langsung dengan para petani Brokoli dengan menggunakan daftar pertanyaan yang telah disiapkan. 


\section{ב}

Metode Pengambilan Sampel
Penelitian dilakukan terhadap seluruh anggota populasi petani brokoli yang ada di Kelurahan Kakaskasen.

\section{Konsep Pengukuran Variabel}

Variabel dalam penelitian ini adalah:

1. Produksi Brokoli $(\mathrm{Kg})$, yang dihasilkan dalam satu kali musim tanam,

2. Lahan, yakni luas lahan yang ditanami brokoli (ha).

3. Benih yang digunakan dalam satu kali musim tanam.

4. Pupuk kandang yang digunakan pada satu kali musim tanan diukur dalam kilogram..

5. Pupuk Urea yang digunakan pada satu kali musim tanan diukur dalam kilogram..

6. Pupuk NPK yang digunakan pada satu kali musim tanan diukur dalam kilogram.

7. Tenaga kerja yang digunakan dalam satu kali musim tanam (HOK).

8. Harga jual brokoli di tingkat petani dinyatakan dalam rupiah per kilogram

9. Harga pupuk kandang dalam rupiah per kilogram

10. Harga pupuk Urea dalam rupiah per kilogram

11. Harga pupuk NPK dalam rupiah per kilogram

12. Upah tenaga kerja adalah upah per HOK setara pria

\section{Metode Analisis Data}

Analisis yang digunakan dalam penelitian ini adalah Analisis Regresi berganda. Analisis ini digunakan untuk menggambarkan hubungan antara produksi brokoli dengan faktor-faktor produksinya dengan menggunakan fungsi produksi CobbDouglass yang diformulasikan sebagai berikut :

$\mathrm{Yi}=\beta_{0} \mathrm{X}_{1}{ }^{\beta 1} \mathrm{X}_{2}{ }^{\beta 2} \mathrm{X}_{3}{ }^{\beta 3} \mathrm{X}_{4}{ }^{\beta 4} \mathrm{X}_{5}{ }^{\beta 5} \mathrm{X}_{6}{ }^{\beta 6}+\varepsilon$

Dan dalam bentuk transformasi logaritme natural :

$$
\begin{aligned}
\ln \mathrm{Yi}= & \ln \beta_{0}+\beta_{1} \ln \mathrm{X}_{1}+\beta_{2} \ln \mathrm{X}_{2}+\beta_{3} \ln \mathrm{X}_{3}+ \\
& \beta_{4} \ln \mathrm{X}_{4}+\beta_{5} \ln \mathrm{X}_{5}+\beta_{6} \ln \mathrm{X}_{6}+\varepsilon
\end{aligned}
$$

$\mathrm{Yi}=$ Produksi Brokoli $(\mathrm{kg})$

$\mathrm{X}_{1}=$ Luas Lahan (ha)

$\mathrm{X}_{2}=$ Jumlah Tenaga Kerja $(\mathrm{HOK})$

$\mathrm{X}_{3}=$ Jumlah Benih

$\mathrm{X}_{4}=$ Jumlah Pupuk Kandang ( $\left.\mathrm{kg}\right)$

$\mathrm{X}_{5}=$ Jumlah Pupuk Urea

$\mathrm{X}_{6}=$ Jumlah Pupuk NPK $(\mathrm{kg})$

$\beta_{1}-\beta_{6}=$ Koefisien Regresi variable-variabel di atas

Koefisien regresi dari fungsi tersebut merupakan elastisitas produksi, Ep $=\beta_{i}$. Elastisitas produksi adalah presentase perubahan dari output sebagai akibat dari presentase perubahan input. Selanjutnya setelah $\beta_{\mathrm{i}}$ diperoleh maka efisiensi faktor-faktor produksi dapat dihitung. Efisiensi harga dicapai apabila nilai produk marginal sama dengan harga faktor produksi tersebut :

$$
\begin{gathered}
\frac{\beta_{i} \cdot P_{Y}}{X_{i}}=P_{x i} \\
\mathrm{NPM}_{\mathrm{Xi}}=\mathrm{P}_{\mathrm{Xi}}
\end{gathered}
$$

\section{Dimana :}

$\mathrm{B}_{\mathrm{i}} \quad=$ elastisitas produksi

$\mathrm{Y}=$ produksi rata-rata

$\mathrm{X}=$ faktor produksi rata-rata

$\mathrm{P}_{\mathrm{Y}} \quad=$ harga produksi rata-rata

$\mathrm{P}_{\mathrm{xi}} \quad=$ harga faktor-faktor produksi rata-rata dari input $\mathrm{x}_{\mathrm{i}}$

$\mathrm{B}_{\mathrm{i}}$ merupakan elastisitas atau Ep dimana :

Ep $<01$,penggunaan faktor produksi belum efisien secara teknis

$\mathbf{0}<\mathbf{E p}<\mathbf{1}$,penggunaan faktor produksi sudah efisien secara teknis

EP >1,penggunaan faktor produksi belum efisien secara teknis

dimana : 


\section{HASIL DAN PEMBAHASAN}

\section{Deskripsi Usahatani Brokoli di Kelurahan Kakaskasen}

Rata-rata penggunaan faktor produksi pada usahatani brokoli di Kelurahan Kakaskasen dapat dilihat pada Tabel 1.

\begin{tabular}{cccc} 
Tabel 1. Rata-rata Penggunaan Faktor-faktor & $\begin{array}{c}\text { Produksi pada Usahatani } \\
\text { Kelurahan Kakasksen. }\end{array}$ \\
$\begin{array}{c}\text { Nokoli di } \\
\text { No }\end{array}$ & $\begin{array}{c}\text { Faktor } \\
\text { Produksi }\end{array}$ & Rata-rata & $\begin{array}{c}\text { Rata- } \\
\text { rata/Ha }\end{array}$ \\
\hline 1 & $\begin{array}{c}\text { Luas Lahan } \\
\text { (Ha) }\end{array}$ & 0.41 & 1 \\
& & \\
2 & Benih & 0.048 & 0.118 \\
3 & Pupuk Kan- & 194.83 & 493.83 \\
& dang & & \\
4 & Pupuk Urea & 163.54 & 207.80 \\
5 & Pupuk NPK & 80.83 & 198.33 \\
6 & Tenaga Kerja & 28.6 & 70.94 \\
\hline
\end{tabular}

Sumber: Diolah dari data primer

Luas lahan berkisar antara 0.25 ha sampai $0,5 \mathrm{Ha}$ dengan ata-rata penggunaan lahan pada usahatani brokoli di Kelurahan Kakaskasen adalah 0.41 per hektar.

Benih yang digunakan petani hanya satu macam, dimana pada satu kali musim tanam digunakan 4-5 bungkus benih. Kisaran benih yang digunakan petani antara 0,03-0,06 kg setara dengan $30-60 \mathrm{~g}$ per luasan dengan rata-rata 0,118 per hektar, setara dengan $118 \mathrm{~g}$ per hektar, sedangkan benih brokoli yang direkomendasikan adalah 150$175 \mathrm{~g}$ per hektar.varietas yang digunakan adalah brokoli hibrida F1. Penanaman brokoli petani responden menerapkan sistem tanam pindah, dilakukan persemaian benih terlebih dahulu kemudian ditanam dengan jarak tanam $40-50 \mathrm{~cm}$.

Pupuk yang digunakan adalah pupuk Kandang, Rata-rata $493.83 \mathrm{~kg}$ per hektar, pupuk NPK $198.33 \mathrm{~kg}$ per hektar, pupuk Urea $207.08 \mathrm{~kg}$ per hektar, Pemupukan dilakukan dua kali yaitu pupuk dasar setelah tanam dan pupuk susulan setelah 1 bulan. Dosis pupuk NPK dan pupuk kan- dang masih lebih rendah dari yang direkomendasikan untuk usahatani brokoli yaitu pupuk kandang $500 \mathrm{~kg}$ per hektar dan pupuk NPK 200 per hektar sedangkan dosis pupuk urea sudah melebihi dari rekomendasi yang ada yaitu urea $150 \mathrm{~kg}$ per hektar (Puslitbank Hortikultura 2013) .

Tenaga kerja yang digunakan dalam usahatani Brokoli adalah tenaga kerja dalam keluarga dan tenaga kerja luar keluarga. Tenaga kerja ini dikonversikan ke hari orang kerja setara pria berdasarkan upah.Upah tenaga kerja pria Rp 75.000 per hari dan upah tenaga kerja wanita $\mathrm{Rp} 50.000$ per hari.Jumlah tenaga kerja yang digunakan antara 15-34 HOK atau rata-rata 28.6 HOK per hektar.

\section{Analisis Fungsi Produksi Brokoli}

Hasil analisis yang dilakukan secara bersama-sama faktor produksi, lahan, benih, pupuk dan tenaga kerja di peroleh hasil sebagaimana Tabel 6.

Berdasarkan hasil analisis regresi tersebut dapat diturunkan persamaan regresi hubungan antara produksi dengan faktor-faktor produksi masingmasing.

Dengan menggunakan fungsi produksi Cobb-Douglas maka koefisien regresi (bi) merupakan elastisitas produksi. Elastisitas produksi adalah sebuah konsep yang mengukur derajat respons output terhadap input.

Tabel 6. Hasil Analisis Regresi Fungsi Produksi Brokoli di Kelurahan Kakaskasen

\begin{tabular}{lcccc}
\hline \multicolumn{1}{c}{ Predictor } & Coef & $\begin{array}{c}\text { SE Co- } \\
\text { ef }\end{array}$ & $\mathrm{T}$ & $\mathrm{P}$ \\
\hline \multicolumn{1}{c}{ Constant } & 7.745 & 1.106 & 7.00 & 0.000 \\
Ln Luas & 1.1011 & 0.3532 & 3.12 & 0.005 \\
Lahan & & & & \\
Ln Benih & 0.1550 & 0.2884 & 0.54 & 0.596 \\
Ln pupuk & 0.4143 & 0.1067 & 3.88 & 0.001 \\
kandang & & & & \\
Ln NPK & 0.1323 & 0.2133 & 0.62 & 0.541 \\
Ln Urea & -0.0813 & 0.2033 & -0.40 & 0.693 \\
Ln Tenaga & 0.8702 & 0.1294 & 2.72 & 0.000 \\
Kerja & & & & \\
\hline $\mathrm{S}=0.101065$ & $\mathrm{R}-\mathrm{Sq}=85.5 \%$ & $\mathrm{R}-\mathrm{Sq}(\mathrm{adj})=82.4 \%$
\end{tabular}


Model hubungan antara produksi dengan luas lahan, benih, pupuk kandang, pupuk urea, pupuk NPK dan tenaga kerja sebagai berikut:

\section{$Y=7.745+1.1011$ Ln Luas Lahan + 0.1550 Ln Benih + 0.4143 Ln Pupuk Kandang + 0.1323 Ln Pupuk NPK -0.0813 Ln pupuk Urea + Ln tenaga Kerja 0.0702}

Model tersebut menunjukkan bahwa, naiknya luas lahan cenderung meningkatkan produksi, dimana apabila variabel lainnya konstan, maka naiknya luas lahan sebesar 1 persen akan menaikan produksi sebesar 1.10 persen. Hasil pengujian statistik menunjukan bahwa luas lahan berpengaruh terhadap produksi ( $\mathrm{P}=0.000)$. Nilai elastisitas tersebut menunjukkan bahwa tingkat penggunaan faktor produksi luas lahan belum efisien secara teknis, artinya bahwa untuk mencapai efisien secara teknis maka luas lahan harus ditambah. Namun untuk mendapatkan lahan yang lebih besar, petani membutuhkan modal yang besar padahal di lain pihak petani tidak memiliki modal yang cukup besar untuk membeli sarana produksi yang diperlukan. Kendala satu-satunya yang rasional mengapa petani beroperasi pada daerah satu adalah kendala modal usahatani (Dibertin, 1993).

Penggunaan faktor produksi benih cenderung meningkatkan produksi, dimana naiknya pengunaan benih 1 persen akan meningkatkan produksi brokoli sebesar0.1550 persen (variabel lainnya dianggap konstan) namun secara statistik pengaruh faktor benih tersebut tidak signifikan ( $p>0,20)$. Berdasarkan besaran elastisitas tersebut menunjukkan bahwa penggunaan faktor produksi benih sudah efisien secara teknis $(0<\mathrm{Ep}<1)$. Rata-rata pengunaan benih brokoli yaitu $0.118 \mathrm{~kg} / \mathrm{ha}$.

Penggunaan faktor produksi pupuk kandang cenderung menaikan produksi, dimana naiknya penggunaan pupuk kandang sebesar 1 persen akan menaikan produksi sebesar 0.4143 persen (variabel lainnya dianggap konstan). Pupuk kandang berpengaruh sangat signifikan terhadap produksi brokoli $(\mathrm{p}<0,01)$. Hasil analisis menunjukan bahwa tingkat penggunaan pupuk kandang sudah efisien secara teknis ( $0<$ Ep $<1$ ). Rata-rata pengunaan pupuk kandang $493.83 \mathrm{~kg} / \mathrm{ha}$.

Penggunaan faktor produksi pupuk NPK cenderung menaikan produksi, dimana naiknya penggunaan pupuk sebesar 1 persen akan menaikan produksi brokoli sebesar 0.1323 persen (variabel lainnya dianggap konstan), namun pengaruhnya tidak signifikan $(p>0,20)$. Hasil analisis menunjukan bahwa tingkat pengunaan pupuk NPK sudah efisien secara teknis $\quad(0<\mathrm{Ep}<1)$. Rata-rata pengunaan pupuk $198.33 \mathrm{~kg} / \mathrm{ha}$.

Penggunaan faktor produksi pupuk Urea cenderung mengurangi produksi, dimana naiknya penggunaan pupuk sebesar 1 persen akan menurunkan produksi brokoli sebesar 0.0813 persen (variable lainnya dianggap konstan) namun pengaruhnya tidak signifikan. Hasil analisis menunjukan bahwa tingkat penggunaan pupuk Urea sudah tidak efisien secara teknis $(\mathrm{Ep}<0)$. Rata-rata penggunaan pupuk Urea pada petani responden yaitu $207.08 \mathrm{~kg} / \mathrm{ha}$ sudah melebihi dari rekomendasi.

Penggunaan faktor produksi Tenaga kerja menunjukan pengaruh yang positif terhadap produksi brokoli, dimana naiknya penggunaan tenaga kerja sebesar 1 persen akan meningkatkan produksi brokoli sebesar 0.0702 persen (variabel lainnya dianggap konstan). Pengaruh penggunaan tenaga kerja sangat signifikan terhadap produksi brokoli. Hasil analisis menunjukan bahwa tingkat penggunaan faktor produksi tenaga kerja sudah efisien secara teknis $(0<\mathrm{Ep}<1$ ) Rata-rata pengunaan tenaga kerja $70.93 \mathrm{HOK}$.

Tabel 7 menunjukkan bahwa penggunaan faktor produksi lahan, benih, pupuk kandang, pupuk NPK dan tenaga kerja belum efisien secara ekonomi, sedangkan penggunaan pupuk Urea sudah tidak efisien secara ekonomi. Hal ini berarti bahwa penggunaan faktor produksi tersebut belum mencapai tingkat efisiensi ekonomi, oleh karena itu untuk memperoleh tingkat keuntungan maksimum, faktor produksi lahan, benih, pupuk kandang, pupuk NPK dan tenaga kerja perlu ditambah, sedangkan faktor produksi pupuk urea perlu dikurangi . 


\begin{tabular}{|c|c|c|c|c|c|c|}
\hline Variabel & $\begin{array}{l}\text { Elastisitas } \\
\text { (bi) }\end{array}$ & $\begin{array}{c}\text { Rata- } \\
\text { rata } \\
\text { variabel } \\
(\mathrm{Xi}) \\
\end{array}$ & Py & NPMxi & Px & NPMxi/Px \\
\hline Lahan & 1.1011 & 0.41 & 17.500 & 12685332.7 & 500000 & 25.919 \\
\hline Benih & 0.1550 & 0.048 & 17.500 & 2976155 & 30000 & 99.205 \\
\hline $\begin{array}{l}\text { Pupuk. } \\
\text { kandang } \\
\text { Pupuk }\end{array}$ & 0.4143 & 194.83 & 17.500 & 318198972 & 7500 & 42.426 \\
\hline $\begin{array}{c}\text { NPK } \\
\text { Pupuk }\end{array}$ & 0.1323 & 80.83 & 17.500 & 304835076 & 2500 & 12.193 \\
\hline $\begin{array}{l}\text { Urea } \\
\text { Tenaga }\end{array}$ & -0.0813 & 48.5 & 17.500 & -234156195 & 2000 & -1.170 \\
\hline kerja & 0.8702 & 28.6 & 17.500 & 668348208 & 75000 & 8.911 \\
\hline
\end{tabular}

Ket : Xi= Rata-rata Faktor produksi

$\mathrm{Py}=$ Harga jual produksi rata-rata per $\mathrm{kg}$

NPMxi = Nilai produksi marginal

$\mathrm{Px}=$ Harga faktor produksi rata-rata per $\mathrm{kg}$

$\mathrm{y}=$ Produksi rata-rata 329.16

\section{KESIMPULAN DAN SARAN}

\section{Kesimpulan}

1. Penggunaan Faktor produksi lahan, benih, pupuk dan tenaga kerja, secara bersama-sama berpengaruh nyata terhadap produksi brokoli dikelurahan kakaskasen.

2. Secara teknis, pengunaan factor produksi benih, pupuk kandang, pupuk NPK dan tenaga kerja sudah efisien. Sedangkan penggunaan faktor produksi lahan belum efisien dan penggunaan factor produksi pupuk Urea sudah tidak efisien.

3. Secara ekonomis, penggunaan factor produksi lahan, benih, pupuk kandang, pupuk NPK dan tenaga kerja masih belum efisien, sedangkan penggunaan factor produksi pupuk Urea sudah tidak efisien.

\section{Saran}

1. Untuk meningkatkan produksi baik pada pada petani brokoli masih bisa dimanfaatkan luas lahan. Disamping itu harus ada pengurangan pada penggunaan pupuk Urea.
2. Perlu adanya peran serta pemerintah dalam memberikan penyuluhan tentang penggunaan faktor produksi pada usahatani Brokoli.

\section{DAFTAR PUSTAKA}

Bruce R.C. Beattie, Robert Taylor, 1994. Ekonomi Produksi. Gajah Mada University Press.Yokyakarta

Debertin, D. L. 1993. Agricultural production Economics. Macmillan Publishing Company. New York.

Hernanto, F.1993. “Ilmu Usahatani' Departemen Ilmu Sosial Ekonomi Pertanian. Fakultas Pertanian. Institut Pertanian Bogor.

Heady, E.O. J .L . Dillon, 1961 "Agricultural Production Functions". Iowa State University Press

Mubyarto, 1991."Pengantar Ekonomi Pertanian" LP3ES (Edisi Ketiga). Jakarta. 
Rizky Ramahdani 2010 "Produksi Teori Fungsi \& Efisiensi”.

http://justkie.wordpress.com/2012/06/04/pr oduksi-teori-fungsi-dan-efisiensi/ (di akses September 2012).

Sarma, M. 1985.'Pengantar Ekonomi Pertanian". Fakultas Pertanian IPB. Bogor.
Soekartawi, 2002."Analisis usahatani" UI.Press. Jakarta.

Sugiarto,Tedy Herlambang2010“Ekonomi Mikro Sebuah Kajian Komprehensif" PT Gramedia Pustaka Jakarta. 